<綜 説 $>$

（受理: 平成 16 年 4 月 7 日）

\title{
水性高分子ーイソシアネート系接着剤 \\ Water Based Polymer Isocyanate Adhesives for Wood
}

藤 井 一 郎 ${ }^{*}$

Ichiro FUJII

\section{はじめに}

水性高分子ーイソシアネート系接着剂は, 約 30 年前市 場に登場した。日本接着剤工業会の規格化 (JAI 9/1981) の際には「水性ビニルウレタン系木材接着剤」(Aqueous Vinyl Polymer Solution-Isocyanate Adhesives for wood: 通称 API） と公称され, 現在でも通称「水ビ」 と言う略称にて広く知られている。

その後, 1985 年に日本工業規格にて規格化 (JIS K 6806）された際には「水性高分子ーイソシアネート系木材 接着剤」(Water Based Polymer-Isocyanate Adhesives for wood: 通称 WPI）と言う名称に変わった。

市販された当初は, 従来のホルムアルデヒド系接着剂 と比ベコストが高い事と, 架橋剂の配合後の粘度变化が 大きく, 発泡する等の作業性での問題点も指摘されたが, 反面高い接着性能と木質以外の被着材に対応できる事, また，集成材の製造に於いては従来の接着剤と比較して 圧締時間の短縮による生産性が向上する等の特徴が認め られ使用量が増加した。水性高分子ーイソシアネート系 接着風の近年の生産量推移を図 1 に示す。

1992 年に特認という形で一部の構造用集成材への使 用が可能となり, その後, 特認も 1996 年取り払われて 「構造用集成材の日本農林規格」に小断面集成材への使 用が可能な接着剤としてその名称が記載された。1998年 には，同じく「構造用集成材の日本農林規格」に定義さ

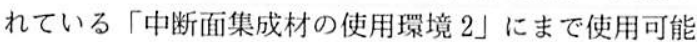
な範井が広がり，現在ではホルムアルデヒド問題による 追い風にあ乗って, 非ホルムアルデヒド系の最右翼の接

\footnotetext{
*株式会社オーシカ 中央研究所 第 2 グループ

東京都板橋区舟渡 145 干 174-0041

OSHIKA CORPORATION

Research \& Development Center

1-4-5 Funato, Itabashi-ku, Tokyo, 174-0041 Japan
}

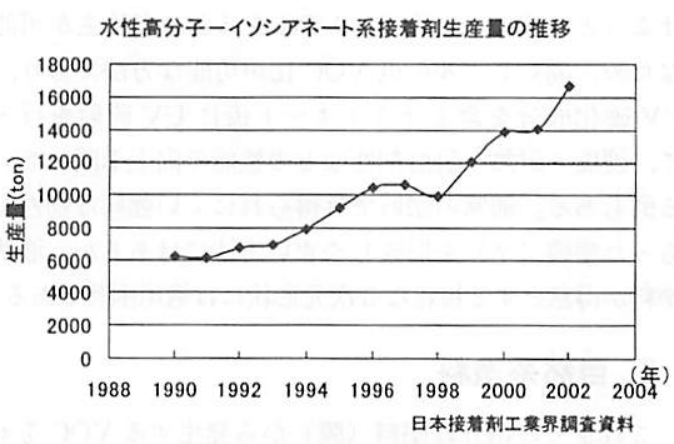

図 1 接着剤の生産量の推移

着剤として需要を伸ばしている。

\section{1. 特 徵}

水性高分子ーイソシアネート系接着剤は, 現在では主 に集成材用の接着剤として使用されているが，木犋材料 の接着だけでなく，無機材料やプラスチックと木質材料 等の接着にも使用されている。

この接着剤の一般的な特徴としては,

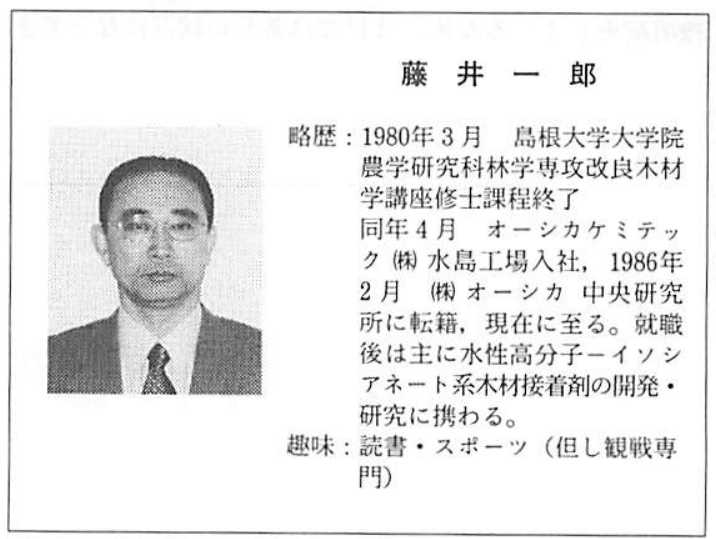


利点

・接着剤糊液は水性なので取り扱いが容易。

· $\mathrm{pH}$ が中性域の為, 木材の変色, 変質が少ない。

・接着強さの立ち上がりが早く, 圧締時間の短縮が可能。

・冷圧, 熱圧, 高周波印加加熱プレス等幅広い接着方法 が可能。

・木材だけでなく，無機材料，金属，プラスチック等と 木質材料の接着が可能。

・耐水, 耐久性能に優れ住宅建材としてレソルルシノール 樹脂系接着剤に匹敵する性能を有する。

・ホルムアルデヒド, フェノール，アミン等の原料を使 用していない。

問題点

- 架橋剂配合後, 時間経過ととあに耐水性能の低下があ る。(可使時間に制限がある)

・架橋剤配合後に增粘, 発泡がある。

・堆積時間の影響を受け易く作業時間に制限がある。 (乾燥し易い)

・機械などに付着した乾燥皮膜の除去が困難。

・ュリア樹脂系接着剂と比較するとコストが高い。

注意点としては, 接着剤が皮膜を形成するためには接 着剤中の水分揮散が必要なこと, また，イソシアネート が水との反応により炭酸ガスを発生するので, 被着材の 一方が必ず水分が浸透し，ガスを透過する木材の様な多 孔質な材料であることが必要である。

\section{2. 組 成}

接着郕組成として, 活性水素 $(-\mathrm{H})$ を有する主剤と イソシアネート系の架橋剤とを混合することにより接着 剂の硬化皮膜に高度な耐水性を付与する事が出来る接着 剂である。

主剤の組成としては, ポリビニルアルコール水溶液と, 水性高分子エマルジョン（酢酸ビニル系, エチレン酢酸 ビニル系, アクリル酸エステル系, スチレンーブタジエ ン系, アクリロニトリループタジェン系等) と, 炭酸力 ルシウムなどの無機物質等を主成分とした混合物である。

架橋剤はジフェニルメタンジイソシアネート (MDI) などのジイソシアネート化合物類（図2）を主成分とし ている。通常は, 使用時に要求性能により主剤に対し 5 〜20 部添加される。

商品化された当初の主剤組成は主にポリピニルアルコー ル（図3），スチレンーブタジェン共重合体（図 4), 炭 酸カルシウムが主流であったが, 接着性能の向上や圧締 時間の短縮を可能とするために, 酢酸ビニル樹脂（図 5)

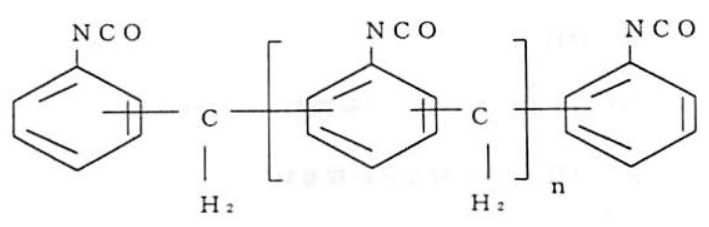

図 2 イソシアネート

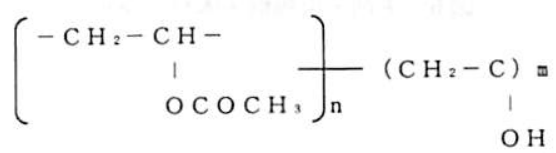

図 3 ポリピニルアルコール

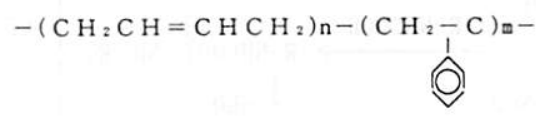

図4スチレンーブタジェン

$\left(-\mathrm{CH}_{2}-\mathrm{CH}-\right) \mathrm{n}$

$\mathrm{O} \mathrm{COCH}$

図 5 酢酸ビニル

を代表とする各種の水性高分子エマルジョンが使用され ている。ポリビニルアルコールは種類によりヶン化度, 重合度, 変性などにより性能, 性状を変化することが出 来る。水性高分子エマルジョンは, その組成, $\mathrm{Tg}$, 変 成等の項目を調整する事により耐水性能を含む接着性能 の調整や，圧締時間を左右する初期接着性能発現性の調 整が可能となるものなど, 接着剤に要求される性能を調 整出来る原料である。この様に, 水性高分子ーイソシア ネート系接着剂は，原料の配合技術により異なった性能 の接着剤を設計できると言う特徵により, 広範囲の接着 条件に対応できる接着郕である。

\section{3. 反応機構}

水性高分子ーイソシアネート系接着剤の反応の特徴と しては, 架橋㓮として用いるインシアネート化合物を主 剂中の活性水素 $(-\mathrm{H})$ との反応以外にも被着材（木材 中の水酸基 $(-\mathrm{OH}))$ との間で図 6 の様にイソシアネー ト基（-NCO）を反応させウレタン結合となることを勘 ている。

しかし，イソシアネート基は図 7 の様に主剤中に含ま れる水と反応しカルバミン酸となり, 炭酸ガスを発生し アミンを形成する。このアミンは更に-NCO と反応して ユリアとなる。一方カルパミン飘の一部は更にーNCO 
$\mathrm{R}-\mathrm{OH} \quad$ （主都）

OCN-R-NCO

(架橋鼡(イリシアネート))

$+$

$\mathrm{R}-\mathrm{OH} \quad$ （木材などの被着材）

$\downarrow$

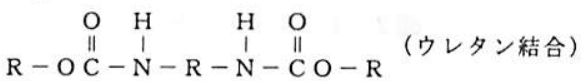

図 6 主偊・架橋鼡・木材の反応

\section{R-NCO}<smiles>C[14CH2]O</smiles>
$+\mathrm{R}-\mathrm{NCO}$

$\mathrm{R}-\mathrm{NHCOOH}$ (1)$+R-N C O$ $\mathrm{R}-\mathrm{NHCOOCOHN}-\mathrm{R}$<smiles>CCCC(=O)O</smiles>
$\mathrm{R}-\mathrm{NH}_{2}$ (2) $\stackrel{+\mathrm{R}-\mathrm{NHCOOH}}{\longrightarrow}[\mathrm{R}-\mathrm{NHCOO}]\left[\mathrm{NH}_{3}-\mathrm{R}\right]$<smiles>CC[PH2]NC=[GeH2]</smiles>
$[\mathrm{R}-\mathrm{NH}]_{2} \mathrm{CO}$

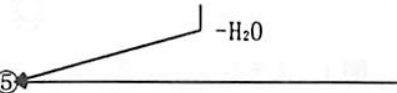

$\downarrow+\mathrm{R}-\mathrm{NCO}$

R-NHCON-R-COHN-R (6)

(1) : カルバミン酸 (2):アミン

(3)：アンモニウム塩 (4)：カルバミン酸無水物

(5) : ユリア (6) : ビウレット

図 7 イソシアネートと水系の反応
に塗布した場合には水分は木材に浸透して揮散するので， イソシアネート基が水と反応するのを抑えることができ るため，混合した接着剤はできるだけ早く使用した方が よい。

\section{4. 品 質}

品質はJIS K 6806 「水性高分子ーイソシアネート系 木材接着剤」に定められており, 2003 年 3 月の改正で 新たにホルムアルデヒド放散による区分が設けられた。

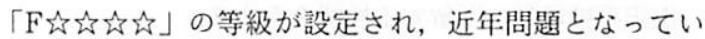
る接着風から放散するホルムアルデヒドを規制する内容 となっている。

表 1 JIS K 6806 に記載される品質

\begin{tabular}{l|c|c|c|c}
\hline \multirow{2}{*}{ 試験項目 } & \multirow{2}{*}{ 単位 } & \multirow{2}{*}{ 試験条件 } & \multicolumn{2}{|c}{ 品澌 } \\
\cline { 4 - 5 } & & & 主剤 & 架橋剤 \\
\hline 外钼 & - & - & $\begin{array}{l}\text { 異物の混入か } \\
\text { ない }\end{array}$ & $\begin{array}{l}\text { 均質な液状で } \\
\text { ある }\end{array}$ \\
\hline 不揮発分 & $\%$ & $105 \pm 1.5^{\circ} \mathrm{C}$ & 30.0 以上 & - \\
\hline 粘度 & $\mathrm{Pa} \cdot \mathrm{s}$ & $23 \pm 0.5^{\circ} \mathrm{C}$ & 0.1 以上 & $0.01 \sim 3.5$ \\
\hline $\mathrm{pH}$ & - & $23 \pm 1^{\circ} \mathrm{C}$ & $3.5 \sim 8.5$ & - \\
\hline 水混和性 & $($ 倍 $)$ & $23 \pm 1^{\circ} \mathrm{C}$ & 2 以上 & - \\
\hline 保存性 & $\mathrm{H}$ & $60 \pm 2^{\circ} \mathrm{C}$ & 15 以上 & - \\
\hline $\mathrm{NCO}$ 量 & $\%$ & - & - & 10 以上 \\
\hline
\end{tabular}

表 2 JIS K 6806 に記载される性能

\begin{tabular}{|c|c|c|c|c|c|c|c|}
\hline \multirow{3}{*}{\multicolumn{2}{|c|}{ 試験項目 }} & \multirow{3}{*}{ 単位 } & \multirow{3}{*}{ 試験条件 } & \multicolumn{4}{|c|}{ 性能 } \\
\hline & & & & \multicolumn{2}{|c|}{1 種 } & \multicolumn{2}{|c|}{2 種 } \\
\hline & & & & 1 号 & 2 号 & 1 号 & 2 号 \\
\hline \multirow{3}{*}{$\begin{array}{l}\text { 王縮せん } \\
\text { 断接着強 } \\
\text { さ }\end{array}$} & 常態 & $\mathrm{N} / \mathrm{cm}^{2}$ & - & 981 以上 & 981 以上 & - & - \\
\hline & 耐温水 & $\mathrm{N} / \mathrm{cm}^{2}$ & $60 \pm 3^{\circ} \mathrm{C}$ 温水 3 時間 & - & 588 以上 & - & - \\
\hline & $\begin{array}{l}\text { 煮沸繰 } \\
\text { り返し }\end{array}$ & $\mathrm{N} / \mathrm{cm}^{2}$ & $\begin{array}{l}\text { 沸滕水中 } 4 \text { 時間 } \\
60 \pm 3^{\circ} \mathrm{C} 20 \text { 時間 } \\
\text { 沸滕水中 } 4 \text { 時問 }\end{array}$ & 588 以上 & - & - & - \\
\hline \multirow{3}{*}{$\begin{array}{l}\text { 合板 } \\
\text { 引っ張り } \\
\text { せん断接 } \\
\text { 着强さ }\end{array}$} & 常態 & $\mathrm{N} / \mathrm{cm}^{2}$ & - & - & - & 118 以上 & 118 以上 \\
\hline & 耐温水 & $\mathrm{N} / \mathrm{cm}^{2}$ & $60 \pm 3^{\circ} \mathrm{C}$ 温水 3 時問 & - & - & - & 98 以上 \\
\hline & $\begin{array}{l}\text { 劣沸繰 } \\
\text { り返し }\end{array}$ & $\mathrm{N} / \mathrm{cm}^{2}$ & $\begin{array}{l}\text { 沸滕水中 } 4 \text { 時間 } \\
60 \pm 3^{\circ} \mathrm{C} 20 \text { 時間 } \\
\text { 沸滕水中 } 4 \text { 時間 }\end{array}$ & - & - & 98 以上 & - \\
\hline \multicolumn{2}{|c|}{ 接着強さ保持時間 } & $\min$ & $23 \pm 0.5^{\circ} \mathrm{C}$ & \multicolumn{4}{|c|}{10 以上 } \\
\hline
\end{tabular}

と反応しカルパミン酸無水物となる。ユリアは更に反応 してビウレットを生成する。接着剤糊液が発泡するのは この反応の際に生じた炭酸ガスによるものである。

主剤と架橋凪の配合後に可使時間に制限が生じるのは イソシアネート基が目的の- $\mathrm{OH}$ 基と反応する前に水と 反応して消費されてしまうためである。また，木材など
この内容は接着剤に,「ユリア樹脂, メラミン樹脂, フェノール樹脂, レソルシノール樹脂, ホルムアルデヒ ド系防腐剂，メチロール基含有モノマー及びロンガリッ ト系触媒のいずれも使用してはならない」としている。 JIS の定める品質と性能を表 1 及び表 2 示す。 


\section{5. 使用方法亡特徵}

接着羭の使用方法と性能を, 水性高分子ーイソシアネー ト系接着刜PI-I を例に紹介する。

\section{1 架橋剤添加量と接着性}

架橋剂の添加量を 0 部から 20 部まで变化し, その時 の接着性能をJIS K-6806に準じたカバ材の圧縮せん 断接着強さ（煮沸繰り返し試験）にて傾向を見た。（図 8)

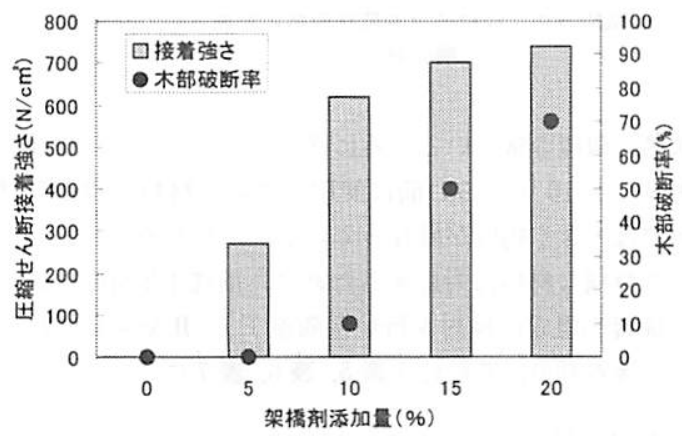

図 8 接着剂 PI-I を用いた架橋剂添加量と接着強さの関係 圧縮せん断試験（惹沸繰り返し試験）

架橋剂添加量 0 部の主剂のみで接着した場合は当然の 事ながら耐水性能は発現していない。架橋凪添加量 10 部以上でJIS K-6806の定める接着強さを発現してい る。この様に架橋阂の配合比率を増加する事により, 耐 水性を向上することが出来る。但し次項目の架橋剤配合 後の経過時間とともに耐水の接着強さが低下することを 考虑すると 15 部以上の添加が望ましい。また，20 部以 上の添加では接着剤の粘度変化が大きくなる為使いにく くなり，接着剤によっては被着材への濡れ性低下により 接着珄能が低下する場合もある。

\section{2 架橋剤配合後の経過時間と接着性}

架橋剤添加量を標準仕様の 15 部とし，接着刜の温度 を $20^{\circ} \mathrm{C}$ と $35^{\circ} \mathrm{C}$ 条件での架橋剤添加後の経過時間と接着 性能の関係を調べた。（図 9）

経時とともに耐水接着性能の低下が見られる。これは イソシアネートが接着剤中の水分と反応し消費されてい る結果と思われる。

\section{3 堆積時間と圧締時間}

接着凪の不揮発分を調整する事で，堆積時間，圧締時 間の調整が出来る。

接着阂の硬化は接着層の乾燥による被膜形成速度によ り左右される。従って, 接着剤不揮発分を高くして乾燥 速度を速めることにより圧締時間を短縮することが出来 る。（表 $3 ）$

また, 逆に, 不揮発分を低くする事により乾燥速度を

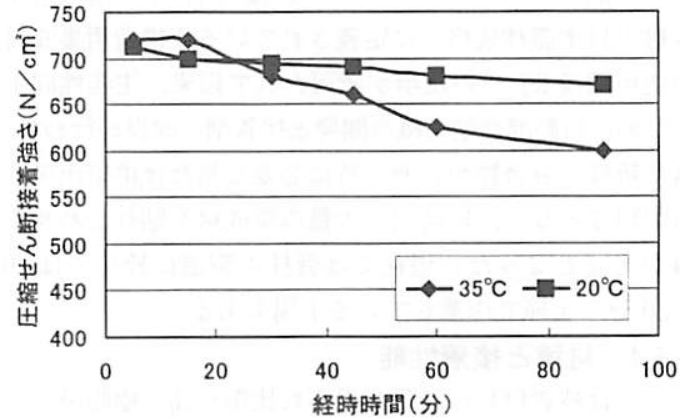

図 9 接着剤 PI-I を用いた架橋剤添加後の経時と接着性能 の関係圧縮せん断試験（煮沸綝り返し試験）

表 3 不揮発分と堆積時間

\begin{tabular}{c|c|c}
\hline 堆積時間 & 不揮発分 $60 \%$ & 不揮発分 $40 \%$ \\
\hline 0 分 & $0 \%$ & $0 \%$ \\
\hline 5 分 & $0 \%$ & $0 \%$ \\
\hline 10 分 & $0 \%$ & $0 \%$ \\
\hline 15 分 & $3 \%$ & $0 \%$ \\
\hline 20 分 & $9 \%$ & $0 \%$ \\
\hline
\end{tabular}

表中数值：はく離率

接著条件：被着材レッドウッド

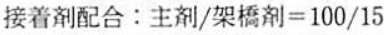

㕵布量 : $250 \mathrm{~g} / \mathrm{m}^{2}$

圧締 : $1.2 \mathrm{MPa}$

試験方法：構造用集成材の日本農林規格に記載され 万隇圧加圧試験

表 4 不揮発分と圧締時間

\begin{tabular}{c|c|c}
\hline 圧締時間 & 不揮発分 $60 \%$ & 不揮発分 $40 \%$ \\
\hline 10 分 & $4 \%$ & - \\
\hline 20 分 & $0 \%$ & $9 \%$ \\
\hline 30 分 & $0 \%$ & $6 \%$ \\
\hline 40 分 & $0 \%$ & $0 \%$ \\
\hline 50 分 & $0 \%$ & $0 \%$ \\
\hline
\end{tabular}

表中数値：はく離率

接着条件：被着材レッドウット

接着剂配合: 主剂/架橋剂 $=100 / 15$

壁布量 : $250 \mathrm{~g} / \mathrm{m}^{2}$

压締 : $1.2 \mathrm{MPa}$

試験方法：構造用集成材の日本農林規格に記載され る隇圧加圧試験

遅くして堆積時間を長くする事が出来る。（表 4）

しかし，圧締時間の短樎を目的として設計した場合， 雾囲気温度が高いと乾燥が早くなり, 接着剤を惩布して から圧締を行うまでに過乾燥による接着不良を起こして しまう危険性がある。従って, 堆積時間に制限が生じる と言う問題は残る。 
水性高分子ーイソシアネート系接着剤が，「構造用集 成材の日本農林規格」に定義されている「構造用集成材 の使用環境 $2 」 へ の$ 使用が認可されて以来, 生産性向上 のために自動混合塗布機の開発之接着剤の改良が行われ, 常に新鮮な混合物が必要な時に必要な量だけ供給出来る 事が可能となり，短時間で大量の集成材を貼り合わせる 事が可能となった。現在では管柱の製造に於いては 20 ～30 分の圧締で作業している工場もある。

\section{4 材種之接着性能}

近年は被着材料に变化が見られ比重が高く樹脂分の多 い材料が使用される場合がある。これは木材の伐採地が

表 5 圧縮せん断試験

\begin{tabular}{l|c|c}
\hline 項 目 & 接着剤 PI-II & 接着剤 PI- I \\
\hline 常 態 & $1764(100)$ & $1991(93)$ \\
\hline 耐温水 & $875(93)$ & $833(50)$ \\
\hline 煮沸繰り返し & $767(85)$ & $690(45)$ \\
\hline
\end{tabular}

表中数値：接着強さ： $\mathrm{N} / \mathrm{cm}^{2}$

（）内：木部破断率 $(\%)$

接着条件：被着材 : $10 \mathrm{~mm}$ 厚 カバ $2 \mathrm{ply}$ 比重 0.76

接者剂配合 : 主剤/架橋剤 $=100 / 15$

その他：JIS J 6806 に準拋

表 6 構造用集成材の接着性能試験

\begin{tabular}{l|c|c}
\hline \multicolumn{1}{c|}{ 被着材樹種 } & 接着剤 PI-II & 接着剤 PI-I \\
\hline スプルース & $0 \%$ & $0 \%$ \\
\hline ベイマッ & $0 \%$ & $0 \%$ \\
\hline レッドゥッド & $0 \%$ & $0 \%$ \\
\hline ヒノキ & $0 \%$ & $1 \%$ \\
\hline ダフリカカラマッ (a) & $0 \%$ & $2 \%$ \\
\hline ダフリカカラマッ (b) & $0 \%$ & $7 \%$ \\
\hline
\end{tabular}

表中数値：はく離染

接着条件: 被着材 : $20 \sim 30 \mathrm{~mm}$ 厚 $5 \mathrm{ply}$

接着剂配合：主剂/架橋剂 $=100 / 15$

染布量 : $250 \mathrm{~g} / \mathrm{m}^{2}$

圧締： $1.2 \mathrm{MPa} \times 40$ 分

試験方法：構造用集成材の日本農林規格に記載される減圧加 压試験
表 7 造作用集成材の接着性能試験

\begin{tabular}{l|c|c}
\hline 被着材樹種 & 接着剤 PI-II & 接着剤PI-I \\
\hline タモ & $0 \%$ & $0 \%$ \\
\hline ナラ (a) & $0 \%$ & $0 \%$ \\
\hline ナラ (b) & $0 \%$ & $7 \%$ \\
\hline
\end{tabular}

表中数値：はく離率

接等条件：被举材：24 $27 \mathrm{~mm}$ 厚 $5 \mathrm{ply}$

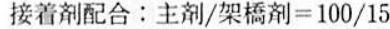

染布量 $: 250 \mathrm{~g} / \mathrm{m}^{2}$

压締: $1.2 \mathrm{MPa} \times 40$ 分

試験方法：成材の日本農林規格に記载される浸せき はく離試験

次第に環境の厳しいところに移ったためで，同じ樹種で あっても 10 年くらい前に使用していた材料と現在の材 料では大きく物性が異なっている場合がある。

この様な材料に対応するために, 前述 1.2 組成に述べ た接着剂組成の検討を行い接着剂 P I - II を開発した。 この接着剂の接着性能を表 5 , 表 6 , 表 7 に示す。

\section{おわりに}

水性高分子ーイソシアネート系接着剤は, 最近大きな 社会問題となっているホルムアルデヒド等 VOC 物質が 原因と言われている「シックハウス症候群」に対応出来 る接着凨として浮上してきている。その需要に応えるた めにも, 配合組成の組み合わせにより様々な変成が可能 であると言う特徴を生かして, 顧客からの更なる要求性 能を満足出来るよう技術改良を行う事により, その需要 が更に伸びる事が予想される。

\section{引 用 文 献}

1） 日本接着剂工業会 会報 1990 ２002 年

2）木材の接着・接着剬P131（社）日本木材加工技術協会

3） JIS K-6806 2003 P1, 2（財）日本規格協会

4）接着ハンドブック第 3 版 P 467〜 469 日本接着学会 